\title{
The Role of the Pituitary-Growth Hormone-IGF Axis in Glucose Homeostasis
}

\author{
Stephen F. Kemp \\ University of Arkansas for Medical Sciences \\ Arkansas Children's Hospital \\ U. S. A.
}

\section{Introduction}

Hypoglycemia results when either carbohydrate intake is low, tissue use is high (glycolysis or glucagons synthesis), or endogenous production of glucose is low (glycogenolysis and glyuconeogenesis)(Berry, Nathan et al. 2009). Glucose levels are controlled by the hormone insulin, and also by the counterregulatory hormones glucagons, cortisol, growth hormone $(\mathrm{GH})$, epinephrine, and norepinephrine. The counterregulatory hormones stimulate production and release of glucose. Hypoglycemia is the most common metabolic problem in neonates, and is also seen in children and adults.

\section{The pituitary-growth hormone-IGF axis}

\subsection{Embryology of the pituitary gland}

The pituitary gland develops from invagination of the oral ectoderm (Rathke's pouch)(Frohnert and Miller 2009). Nearby neuroectoderm becomes the posterior pituitary, which secretes the hormones oxytocin and vasopressin. Signalling factors involved in the initial differentiation of the anterior pituitary (thickening of the oral ectoderm) include the transcription factors HESX1, PITX1, LHX3, and LHX4. Under the influence of the transcription factor TPIT some of the cells develop into corticotrophs which secrete ACTH. When influenced by transcription factors PROP1, PIT1 (now called POU1F1), PITX1 and PITX2 the remaining cells differentiate into gonadotrophs (which secrete FSH and LH), thyrotrophs (which secrete TSH), somatotrophs (which secrete GH), and lactotrophs (which secrete PRL). During this process the oral ectoderm and the neuroectoderm remain in contact with each other, and both migrate together to form the pituitary with distinct anterior and posterior lobes. All of the hormones of the anterior pituitary are influenced by secretions from the hypothalamus and are regulated through specific feedback loops. Two hormones of the anterior pituitary protect against hypoglycemia- GH and ACTH. ACTH stimulates secretion of cortisol by the adrenal gland. Both $\mathrm{GH}$ and cortisol protect against hypoglycemia by countering the effects of insulin.

\subsection{The GH-IGF system}

The GH/IGF axis is shown in Figure 1. It is regulated by three peptides, two from the hypothalamus (that part of the brain closest to the pituitary gland) (Growth Hormone 


\begin{tabular}{|l|l|}
\hline Transcription Factor & Function \\
\hline HESX1 & Involved in formation of Rathke's pouch \\
\hline PITX1 & $\begin{array}{l}\text { Formation of pituitary. Involved in differentiation of pituitary } \\
\text { cell into a corticotroph (secreting ACTH) or a gonadotroph } \\
\text { (LH/FSH) }\end{array}$ \\
\hline LHX3 & $\begin{array}{l}\text { Formation of pituitary. Differentiation of pituitary cell into a } \\
\text { somatotroph (GH) or a lactotroph (PRL) }\end{array}$ \\
\hline LHX4 & $\begin{array}{l}\text { Formation of pituitary. Differentiation of pituitary cell into } \\
\text { precursor for gonadotrophs, thyrotrophs, samatotrophs, and } \\
\text { lactotrophs. }\end{array}$ \\
\hline SF1 & $\begin{array}{l}\text { Formation of pituitary. Differentiation of pituitary cell into } \\
\text { precursor for gonadotrophs, thyrotrophs, samatotrophs, and } \\
\text { lactotrophs. }\end{array}$ \\
\hline TPIT & Differentiation of gonadotrophs. \\
\hline NEUROD1 & Differentiation of corticotrophs. \\
\hline POU1F1 (PIT1) & Differentiation of corticotrophs \\
\hline PROP1 & $\begin{array}{l}\text { Differentiation of cells into precursors of thyrotrophs, } \\
\text { somatotrophs, and lactotrophs. }\end{array}$ \\
\hline
\end{tabular}

Table 1. Transcription factors involved in the differentiation of the anterior pituitary.

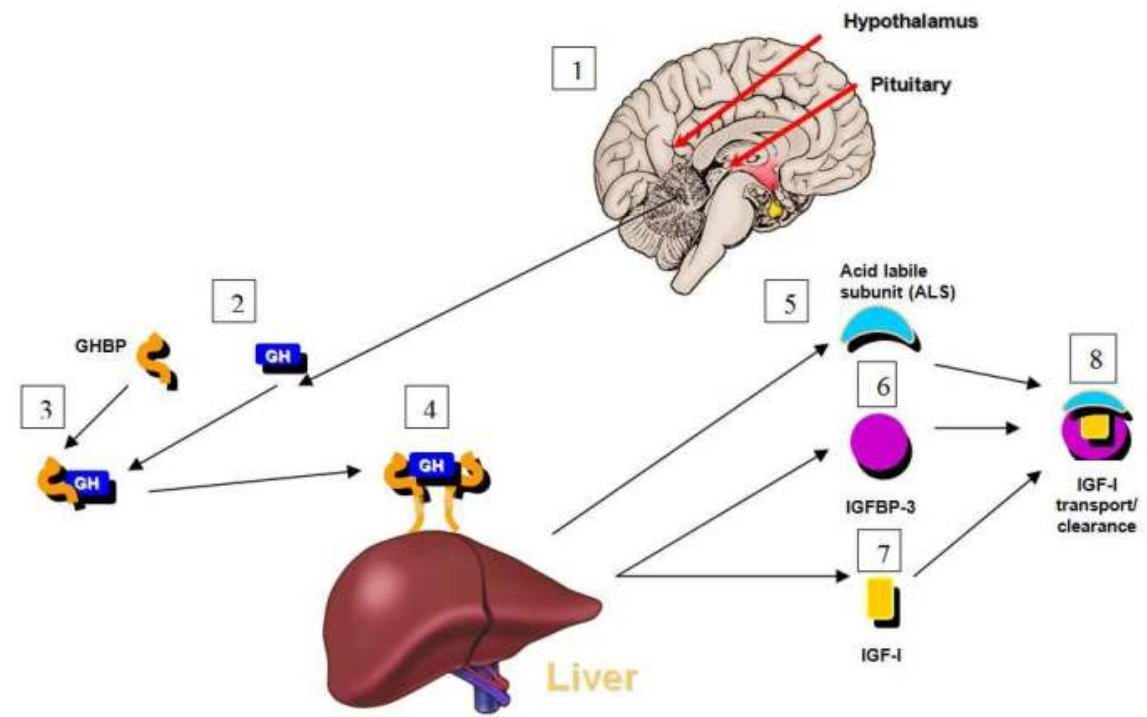

Fig. 1. The Hypothalamic-GH-IGF system 1. The hypothalamus secretes GHRH and somatostatin. 2. GH is secreted into the general circulation. 3. GH circulates bound to its binding protein, GHBP. 4. GH binds to the GH receptor. 5. ALS, 6. IGFBP-3, and 7. IGF-I circulate together in a $140 \mathrm{kDa}$ complex. 8. IGF-I acts at the growth plate. 
Releasing Hormone (GHRH) and somatostatin), and one from the gastrointestinal tract (ghrelin). Growth hormone releasing hormone (GHRH), signals the pituitary to secrete GH into the general circulation. The other hypothalamic signal is somatostatin, which inhibits GH secretion. These two signals alternate in their expression, so that when GHRH is high, somatostatin is low, and vice versa. The third factor, ghrelin, also stimulates GH secretion. GH is secreted in discrete bursts, and, once secreted, remains in circulation for about 20 mintues.

$\mathrm{GH}$ circulates bound to $\mathrm{GH}$ binding protein (GHBP), which in humans is identical to the extracellular portion of the GH receptor. GHBP is produced as a result of cleavage of the extracellular portion of the GH receptor. In order for $\mathrm{GH}$ to act two GH molecules bind to adjacent $\mathrm{GH}$ receptors, resulting in a conformational shift in the GH receptor, which activates the JAK-STAT pathway in the cell. Activation of the JAK-STAT pathway initiates a cascade of intracellular events, ultimately increasing production of Insulin-like Growth Factor I (IGF-I). GH stimulates statural growth by action directly at the growth plate and indirectly through the production of IGF-I. The name growth hormone is somewhat unfortunate, in that it suggests that its only function is to stimulate growth. In addition to its involvement in the growth process, GH has many metabolic functions, such as increasing muscle mass and bone mineral density. Generally, the effects of GH are anabolic.

There are two GH genes, located on chromosome 17 in the human, GH-1 and GH-2. The GH-1 (or GH-N) gene encodes for GH. It consists of five exons separated by four introns (Parks, Nielson et al. 1985). The most abundant hormone of the pituitary gland, GH is a single chain a-helical non-glycosylated polypeptide consisting of 191 amino acids with two intramolecular disulphide bonds between amino acid 52-165 and 282-189. Different forms of $\mathrm{GH}$ exist with the most common form of GH being the one with a molecular weight of 22$\mathrm{kD}$, which accounts for about $75 \%$ of the GH produced in the pituitary gland. Alternative splicing of the second codon results in a $20-\mathrm{kD}$ form that make up about $5-10 \%$ of the total GH. There is structural homology between the GH molecule and prolactin and human placental lactogen (human chorionic somatotropin), suggesting that they may all have descended from a common ancestral gene.

$\mathrm{GH}$ acts by binding to its receptor primarily at two sites, the liver and the growth plate. In the liver activation of the GH receptor stimulates production of IGF-I, its binding protein IGFBP-3, and the acid labile subunit (ALS). Growth hormone circulates at least $50 \%$ bound to its binding protein, GHBP (Rosenfeld 2005). It binds specifically with high affinity and low capacity. In humans the circulating GHBP is actually the extracellular domain of the GH receptor; it is thought that GHBP is shed or cleaved from intact receptors. The physiological significance of $\mathrm{GH}$ binding by GHBP is not completely understood; it may act to prolong the half-life of GH in the serum or it may compete with the GH receptor for binding.

Insulin-like growth factors (IGF-I and IGF-II) are small peptide hormones ( 7.5 kDa) which share a high degree of homology with proinsulin (Rinderknecht and Humbel 1978; Rinderknecht and Humbel 1978). Almost ubiquitously produced, they circulate at high concentrations in serum. Beyond their insulin-like effects, these growth-promoting peptides influence cellular proliferation and differentiation in numerous tissues, including at the growth plate (Nilsson, Marino et al. 2005). For IGFs to exert their effects at the cell surface, they must first bind specific, high affinity cell-surface receptors, principally the type I IGF receptor. The interaction of IGFs with cell-surface receptors, however, is tightly regulated by at least six distinct high affinity carrier proteins, the IGF- binding proteins (IGFBPs). 
IGF-I is the IGF most directly under GH control. It circulates in serum as part of a $140-\mathrm{kDa}$ complex consisting of IGF-I, IGFBP3, and a third $85 \mathrm{KDa}$ factor named acid-labile subunit (ALS) (Baxter 1994). It is probably binding of free (unbound) IGF-I to receptors on chondrocytes in the epiphyseal growth plates that stimulates linear growth. Although the primary site of synthesis of IGF binding proteins is the liver, it has been shown that most tissues produce IGFBPs locally. They may act as part of paracrine and autocrine functions of the IGFs. Functions that the IGFBPs may perform include; 1) increasing the half-life of IGF-I in serum; 2) decreasing binding of IGF-I with the insulin receptor reducing the risk of IGFinduced hypoglycemia; 3) being involved in the transport of IGF-I between the intravascular and the extravascular space ; 4) blocking the local effects of IGF-I; 5) enhancing IGF-I action by keeping the IGF-I in a slowly-releasing pool and 6) modulating cellular proliferation and apoptosis through interaction with receptors other than the IGF-I receptor. Disruption of the IGF:IGFBP:ALS complex is probably a prerequisite for IGFs to exert mitogenic and metabolic effects through the type I IGF receptor.

IGF-I, IGFBP3 and ALS all appear to be regulated by GH, since they are all low in GH deficiency and are restored with GH treatment (Jorgensen, Blum et al. 1991). About $80 \%$ of circulating IGF-I is produced the in the liver (IGF-I and ALS are produced by hepatocytes, while ALS is produced by Kupffer cells and sinusoidal endothelial cells), although locally produced IGF-I may be important for skeletal growth (Sjogren, Liu et al. 1999; Yakar, J. et al. 2002). It is not clear whether GH regulates all components of the 140-kDa complex directly, or whether one of the components may be regulated by $\mathrm{GH}$, which, in turn, regulates synthesis of the others (Binoux 1997). Transcription of the rat ALS gene and ALS promoter activity has been shown to be stimulated by GH (Ooi, Cohen et al. 1997). In Growth Hormone Insensitivity Syndrome (GHIS) the patient is unresponsive to growth hormone; that is, the GHIS patient has high circulating levels of growth hormone, but low circulating levels of IGF-I and IGFBP3. In the case of a patient described with the IGF-I gene deletion (Woods, Camacho-Hubner et al. 1996), there are high circulating levels of growth hormone and low circulating levels of IGF-I, but normal circulating levels of IGFBP3.

\section{$2.3 \mathrm{GH}$ receptor/signaling}

The GH receptor is a member of the cytokine family of receptors. The gene for the human growth hormone receptor is located on chromosome 5p13.1-p12, and spans a region that is greater than $87 \mathrm{~kb}$. The receptor consists of 620 amino acids (molecular weight $70 \mathrm{kD}$ before glycosylation). It is highly homologous with the prolactin receptor, as well as receptors for interleukins 2,3,4,6, and 7, erythropoietin, granulocyte-macrophage colony-stimulating factor, and interferon. The GH receptor has extracellular, transmembrane, and intracellular domains, but it lacks intrinsic tyrosine kinase activity. Similar to other members of the cytokine family of receptors, it uses the JAK-STAT pathway for signal transduction (see Figure 2). Initially GH binds one GH receptor and then recruits a second GH receptor. This dimerization is followed by a conformational shift, which initiates the JAK-STAT cascade. Janus kinase (JAK2) is activated (it is a receptor-associated kinase which both autophosphorylates and phosphorylates the GH receptor). Once phosphorylated, these sites act as docking sites for molecules which undergo phosphorylation by JAK2, resulting in activation of STAT1, STAT3, and STAT5 (STAT stands for Signal Transducers and Activators of Transcription proteins). Once phosphorylated, cytoplasmic proteins form homodimers and heterodimers, travel to the nucleus, and bind specific DNA sequences, which activate gene transcription. 


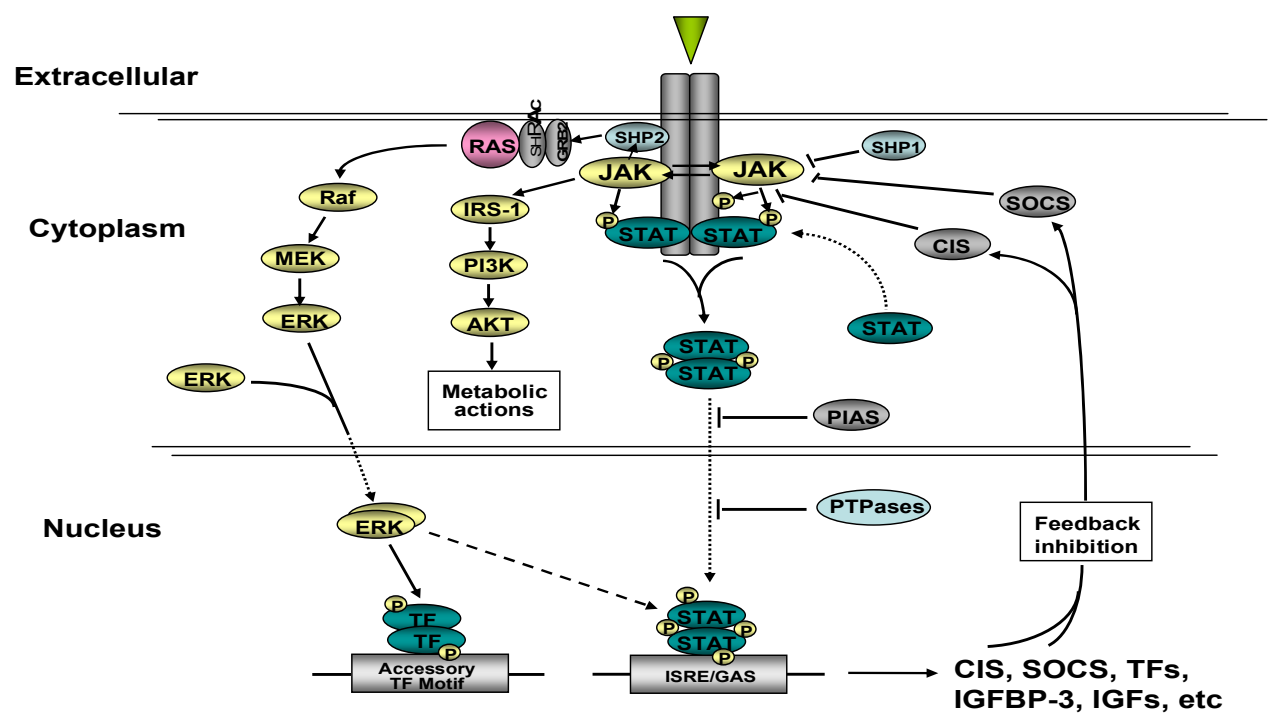

Fig. 2. The JAK-STAT Signalling System: The GH Receptor

\section{GH action}

\subsection{IGF-I}

In 1957 Salmon and Daughaday (Salmon and Daughaday 1957) described a "sulfation factor" to explain the observation that while normal serum stimulated sulfate incorporation into cartilage tissue (a marker for synthesis of glycosaminoglycan, a component of cartilage), this effect was reduced using serum from growth hormone deficient patients, and could not be restored by treating cartilage directly with GH. Sulfation factor was re-named somatomedin, and became the basis of the classical somatomedin hypothesis (Rosenfeld 2005); namely, that most of the actions of growth hormone are carried out by factors originally named somatomedins. At the same time others were studying a compound in the serum which they called "non-suppressible insulin-like activity" (NSILA), whose insulinlike action persisted even after removing insulin by the addition of anti-insulin antibodies. Rinderknecht and Humbel (Rinderknecht and Humbel 1978; Rinderknecht and Humbel 1978) identified and sequenced two proteins, NSILA-I and NSILA-II, which were structurally similar to proinsulin. In the early 1980's it became apparent that NSILA-I and somatomedin $\mathrm{C}$ were identical, which led to the renaming of NSILA-I and NSILA-II to the insulin-like growth factors IGF-I and IGF-II. Of these two proteins IGF-I is the most growth hormone dependent. It is also now apparent that there are distinct cell membrane receptors for insulin, IGF-I and IGF-II. Even though each receptor binds most strongly to its own ligand, there is cross-reactivity among these ligands for all the receptors (see 3.3, below) .

\subsection{IGF proteins}

There are three peptide hormones in the IGF family - insulin, IGF-I and IGF-II (Rosenfeld 2005). Insulin-like growth factors (IGF-I and IGF-II) are small peptide hormones ( 7.5 kDa) which share a high degree of homology with proinsulin. As with insulin, the IGFs have A and 
B chains connected by disulfide bonds, and a C-peptide region that bears no homology with that of proinsulin. IGF-I and IGF-II have a carboxy-terminal extension of variable amino acid lengths. Almost ubiquitously produced, compared with insulin which circulates at picomolar concentrations and has a half-life of minutes, IGF-I and IGF-II circulate at much higher (i. e., nanomolar) concentrations in serum and have much longer half-lives, primarily because they are part of a complex with IGF binding proteins. Beyond their insulin-like effects, these growth-promoting peptides influence cellular proliferation and differentiation in numerous tissues. For IGFs to exert their effects at the cell surface, they first must bind specific, high affinity cell-surface receptors, principally the type I IGF receptor. The interaction of IGFs with cell-surface receptors, however, is tightly regulated by at least six distinct high affinity carrier proteins, the IGF- binding proteins (IGFBPs), and possibly by several low-affinity IGFBP-like molecules. IGFBPs 1-6, which are present in serum and many biologic fluids, have similar or higher affinities for IGF-I and IGF-II than does the type I IGF receptor. Therefore, the interaction of IGFs with IGFBPs can prevent untoward IGF effects, such as uncontrolled cellular proliferation or hypoglycemia. Conversely, disruption of the IGF;IGFBP complex is probably a prerequisite for IGFs to exert their mitogenic and metabolic effects through the type I IGF receptor. It is probably binding of unbound IGF-I to receptors on chondrocytes in the epiphyseal growth plate that stimulates linear growth.

\subsection{IGF receptors}

The IGF-I receptor is similar in molecular structure to the insulin receptor (Rosenfeld 2005); in fact, it has approximately $60 \%$ homology in amino acid composition. There are two membrane-spanning alpha subunits connected by disulfide bonds, which form a pocket that mediates binding of IGF-I. There are two intracellular beta subunits which contain a transmembrane domain, an ATP binding site, and a tyrosine kinase domain that accounts for the presumed signal transduction mechanism for the receptor. The type I IGF receptor binds IGF-I, IGF-II, and insulin with high affinity and mediates the actions of IGF on all tissue specific cell types. Likewise, the insulin receptor can also be bound by IGF-I and IGFII, which means that if either of these growth factors is in abundance in the serum without being part of a larger complex, it can bind the insulin receptor and cause hypoglycemia. IGF-II also binds to a second receptor that has neither an intrinsic tyrosine kinase domain nor a known signal transduction mechanism. This receptor was first called the mannose-6phosphate receptor that binds lysomal enzymes at binding sites distinct from that of IGF-II. Given that this receptor binds mannose-6-phosphate-containing enzymes and to transport them between intracellular compartments, it may serve as a biological sink which would remove IGF-II as well as enzymes such as cathepsin and urokinase from the cellular environment.

\section{Disorders of the pituitary-growth hormone-IGF axis}

\subsection{Congenital hypopituitarism}

Children who are born with lack of pituitary function are at risk for hypoglycemia because they lack ACTH (and, thus, do not produce adequate cortisol) and GH. Male infants with hypopituitarism often present in the newborn period with hypoglycemia and micropenis (because of the inability to secrete the gonadotropins LH and FSH; LH is necessary for testosterone production, which is required for penile growth). In an analysis of a large GH registry (all patients in the registry were being treated with growth hormone) 169 infants 
were identified who presented with hypoglycemia. Of these 148 had hypopituitarism. There were 12 patients with isolated GH deficiency (GHD), and 9 were without hypothalamic or pituitary pathology. Structural central nervous system (CNS) lesions and/or midline facial defects were present in 39\%. Of the males 55\% had micropenis. Eighty-nine percent of the infants required multiple hormone replacement therapy (Bell, August et al. 2004).

A number of developmental occurrences may cause hypopituitarism. These include failure of LHX3 or LHX4. In mice the absence of LHX3 results in Rathke's pouch not growing or differentiating. Three patients were studied from a family with a mutation in LHX3. In humans LHX3 deletion has presented with severe growth failure. Other clinical features have included elevated and anteverted shoulders and a severe restriction of neck rotation, although vertebrae were not abnormal on MRI. The neck conformation appeared to be muscular in origin. One patient with an LHX3 deletion had severe pituitary hypoplasia, one had an enlarged anterior pituitary on MRI, and the third had a pituitary adenoma (Netchine, Sobrier et al. 2000). Individuals with LHX4 deficiency have been shown to be deficient in GH, TSH, and $\mathrm{ACTH}$, and therefore, had short stature at the time of investigation. MRI findings include a small sella turcica with a hypoplastic anterior pituitary, a persistant craniopharyngeal canal, and a Chiari I malformation, as well as an ectopic posterior pituitary ("ectopic bright spot") on MRI. Deletions of LHX4 appear to be transmitted in an autosomal dominant fashion (Machinis, Pantel et al. 2001). Deficiencies in PROP1 ("Prophet of PIT1") may have a small pituitary on MRI, they can present with a large pituitary. They usually have deficiencies in GH, TSH, prolactin, FSH, and LH (Deladoëy, Flück et al. 1999). Mutations in the POU1F1 (formerly PIT1) gene result in deficiencies in GH, prolactin, and the $\beta$-subunit of TSH, but ACTH, FSH, and LH are not affected (HendriksStegeman, Augustijn et al. 2001). At least 14 distinct mutations (some dominant and some recessive) in POU1F1 have been described (Dattani and C. 2000; Hendriks-Stegeman, Augustijn et al. 2001; Malvagia, Poggi et al. 2003; Salemi, Besson et al. 2003) . Both dominant and recessive mutations have been reported. A mutation in the gene HESX1 is associated with hypopituitarism as part of a De Morsier syndrome, also known as Septo-optic Dysplasia (Dattani, Martinez-Barbera et al. 1999). Septo-optic Dysplasia includes optic nerve hypoplasia, midline anomolies (especially absence of the septum pellucidum and occasionally the corpus collosum), and varying degrees of hypopituitarism (usually of the anterior pituitary, but may also include the posterior pituitary) (Brickman, Clements et al. 2001).

Even children born with severe isolated GH deficiency also frequently have hypoglycemia, which usually resolves with GH therapy. A part of the work-up of hypoglycemia is to measure insulin, ketones, free fatty acids, GH, and cortisol levels on a specimen when the blood sugar is hypoglycemic (in children and adults, usually a specimen with a glucose $<50$ $\mathrm{mg} / \mathrm{dl}$ ) (Berry, Nathan et al. 2009). A normal GH response should be a GH level $>10 \mathrm{ng} / \mathrm{ml}$, and a normal cortisol response should be $>15 \mathrm{mg} / \mathrm{dl}$. Elevated free fatty acids and ketones, along with a normal GH and cortisol response suggests hyperinsulinism, which can be further suspected if the insulin level is high. Either low GH or low cortisol alone suggests isolated GH deficiency or cortisol (or ACTH) deficiency. If GH and cortisol are both low, hypopituitarism is suspected. Binder et al.(G., Weidenkeller et al. 2010) have recently suggested that it is possible to diagnose severe congenital GH deficiency in neonates using a random blood sample in which the $\mathrm{GH}$ level is less than $7 \mathrm{mg} / \mathrm{L}$. This test identified infants with GHD with $100 \%$ sensitivity and $98 \%$ specificity. 


\subsection{Idiopathic isolated GH deficiency}

Idiopathic isolated GH deficiency is the most common form of GH deficiency, accounting for as many as $44 \%$ of patients treated with growth hormone (Root, Kemp et al. 1998). Because GH is secreted episodically and GH is present in the serum for only about 20 minutes after it is secreted, random assessment of serum GH levels is rarely helpful. In addition to measuring serum IGF-I and IGFBP3 levels, provocative testing of the GH axis is a means of evaluating a patient suspected of having GH deficiency. Provocative agents which stimulate GH secretion include dopaminergic agents (L-dOPA and clonidine), glucagon, the amino acid arginine, and insulin-induced hypoglycemia. When the pituitary gland was visualized using MRI, as many as $15 \%$ of patients diagnosed as having idiopathic isolated GH deficiency had abnormal findings (Frindik 2001). These abnormalities included small pituitary glands, empty sella tursicas and ectopic posterior pituitaries (i.e., the posterior pituitary had never descended into the sella tursica, but remained near its origin in the brain).

\subsection{Growth hormone insensitivity syndrome}

Growth hormone insensitivity syndrome (GHIS) is a rare autosomal recessive condition characterized by a failure to synthesize insulin-like growth factor-I (IGF-I) in spite of elevated levels of growth hormone. It was first described in 1966 (Laron, Pertzelan et al. 1966), and there have been a variety of different mutations described which account for this condition (Rosenfeld, Rosenbloom et al. 1994), most involving mutations in the growth hormone receptor. GHIS is characterized by growth failure starting in infancy which is unresponsive to $\mathrm{GH}$ administration, associated with elevated levels of $\mathrm{GH}$ and decreased levels of IGF-I and IGFBP3 (Laron, Lillos et al. 1993; Rosenbloom 2000; Savage, Burren et al. 2001). There has been a patient described who had a normal GH receptor, but a mutation in STAT5 (Kofoed, Hwa et al. 2003). A patient has also been described with a similar presentation who has a deletion of the gene for IGF-I (Woods, Camacho-Hubner et al. 1996). Patients with GHIS have frequently reported hypoglycemia without being treated with IGFI. Because there is a GH receptor which is not fully functional, it may be that the hypoglycemia in this condition results from an inability of $\mathrm{GH}$ to function as a glucose counterregulatory hormone, independent of its function in stimulating production of IGF-I.

\section{Treatment of disorders of the pituitary-growth hormone-IGF axis}

\subsection{Treatment of GH deficiency}

Therapy for GH deficiency dates to 1958 when Rabin (Raben 1958) reported using growth hormone isolated from human pituitary glands to treat a patient who was growth hormone deficient. Between 1960 and 1985 human-derived growth hormone was available to treat this population. Because of limited supply, treatment was limited to the most GH deficient patients; in fact, as the supply became more plentiful the criteria for growth hormone deficiency gradually rose from peak GH responses to provocative stimuli of $5 \mathrm{ng} / \mathrm{ml}$ to allow treatment of patients who had peak GH responses to provocative stimuli of $10 \mathrm{ng} / \mathrm{ml}$ in the early 1980's. In 1985 the distribution of human-derived growth hormone was abruptly stopped with the discovery of Creutzfeld-Jacob disease in recipients of these preparations (Brown 1988; Hintz 1995), with the exception of GH deficient patients who experienced hypoglycemia in the absence of GH therapy. At about the same time a recombinant source of growth hormone was approved for use by the FDA, which allowed an almost limitless supply, albeit at a rather expensive cost. Since that time the use of growth hormone in 
treating growth hormone deficiency has expanded and at the same time the number of approved indications for growth hormone therapy has also increased. When GH therapy is used in a patient with GH deficiency who has hypoglycemia, the hypoglycemia usually resolves as soon as treatment is started. The etiology of this effect is somewhat complicated; $\mathrm{GH}$ administration reduces insulin sensitivity, which corrects the hypoglycemia. GH also increases insulin secretion. With GH excess these effects can lead to carbohydrate intolerance, and with GH deficiency they may result in hypoglycemia(Allen, Johanson et al. 1996).

\subsection{Administration of IGF-I}

For populations where treatment with growth hormone is not possible, such as in the case of GH Insenstivity Syndrome, STAT5b deficiency, or IGF-I Deficiency (Woods, CamachoHübner et al. 2000), treatment with IGF-I is now possible. Patents with GHIS or (Laron Syndrome) also frequently report problems with hypoglycemia. Because GH cannot activate the receptor, these individuals have very low concentrations of GH, GHBP-3, and ALS. It is not clear why this situation leads to hypoglycemia. There have been two compounds which have IGF-I as the major component. One, mecasermin, which is rhIGF-I alone (Increlex ${ }^{\mathrm{TM}}$, Tercica, Inc., Brisbane, CA), received approval from the FDA for treatment of severe growth hormone resistance in August, 2005 and approval from the European Agency for the Evaluation of Medical Products (EMEA) in 2007 (Collett-Solberg and Misra 2008). The second compound is mecasermin rinfabate (iPlex ${ }^{\mathrm{TM}}$, Insmed, Richmond, VA). It is a complex of equimolar amounts of rhIGF-I and its most abundant binding protein Insulin-like Growth Factor I binding protein 3 (rhIGFBP-3). The combination of IGF-I and IGFBP-3 was postulated to have the advantage and an increased serum half-life and protection against hypoglycemia, although there was never a head-to-head comparison of the two preparations which compared the propensity for hypoglycemia. Mecaserin rinfabate received approval from the FDA in December 2005, but is no longer available for the treatment of short stature due to a legal agreement (Collett-Solberg and Misra 2008).

Since hypoglycemia risk appears to be dose dependent, hypoglycemia risk has been reduced by dividing the IGF-I dose into two daily injections, twelve hours apart, and it is recommended to give the injection of IGF-I along with a meal. In a recent report, hypoglycemia was reported by $49 \%$ of subjects treated with recombinant IGF-I (Chernausek, Backeljauw et al. 2007). Most hypoglycemic events occurred during the first month of treatment. Seven of the events were reported as severe, and four resulted in seizures. Of the subjects reporting hypoglycemia, 32\% had a history of hypoglycemia before starting treatment with IGF-I. It seemed to occur in younger, shorter subjects who had already had problems with hypoglycemia. This observation seems to be consistent with an earlier report, in which hypoglycemia occurred in some of the patients receiving IGF-I, but at the same rate as in those receiving placebo injections (Guevara-Aguirre, Vasconez et al. 1995), only rarely resulting in seizures (Backeljauw, Underwood et al. 2001). Hypoglycemia was lessened by giving the IGF-I dose with meals, and hypoglycemia was usually a problem when there was an intercurrent illness resulting in loss of appetite.

\section{Summary}

The GH-IGF axis plays an import role in glucose homeostasis, which is somewhat complicated. Growth hormone decreases insulin sensitivity and stimulates insulin secretion. 
Most of the actions of growth hormone take place through Insulin-like Growth Factor-I. IGF-I can bind with the insulin receptor, but under normal circumstances is protected from direct contact insulin receptors, since this $6000 \mathrm{Kda}$ protein circulates bound to Binding Protein 3 and acid labile subunit in a 140,000 Kda complex. With GH deficiency many patients experience hypoglycemia, which is corrected with GH treatment. Growth hormone resistant states also may present with hypoglycemia, but are not sensitive to growth hormone. Treatment of GH resistant states with IGF-I does cause an increase in the linear growth velocity, but IGF-I treatment carries a risk for hypoglycemia, presumably because its similarity to proinsulin allows it to bind the insulin receptor, and it is not protected by its binding protein or ALS.

\section{References}

Allen DB, Johanson AJ, Blizzard RM.. (1996). Growth Hormone Treatment. In: Pediatric Endocrinology, F. Lifshitz, pp. 61-81, Marcel Decker, 0-8247-9369-2 New York

Backeljauw PF, Underwood LE, the GHIS Collaborative Group. (2001). Therapy for 6.5-7.5 years with recombinant insulin-like growth factor I in children with growth hormone insensitivity syndrome: a clinical research center study. Journal of Clinical Endocrinology and Metabolism, 86, 4 (April, 2001), 1504-1510

Baxter RC. (1994). Insulin-like growth factor binding proteins in the human circulation: a review. Hormone Research, 42, 140-144

Bell JJ, August GP, Blethen SL, et al.. (2004). Neonatal hypoglycemia in a growth hormone registry: incidence and pathogenesis. J Pediatr Endocrinol Metab, 17, 4 (April, 2004), 629-35.

Berry SA, Nathan B, Hoffman GF, et al.. (2009). Emergency assessment and management of suspected inborn errors of metabolism and endocrine disorders. In: Pediatric Endocrinology and Inborn Errors of Metabolism. Sarafoglou K, Hoffman GF, Roth KS. pp. 3-16, McGraw Hill Medical, 978-0-07-143915-2, New York

Binoux M. (1997). GH, IGFs, IGF-binding protein-3 and acid-labile subunit: What is the pecking order? European Journal of Endocrinology, 137, 6, (December, 1997), pp 605-609

Brickman JM, Clements M, Tyrell R. et al. (2001). Molecular effects of novel mutations in Hesx1/HESX1 associated with human pituitary disorders. Development, 128, 24 (December, 2001), pp. 5189-99

Brown P. (1988). Human growth hormone therapy and Creutzfeldt-Jacob disease: a drama in three acts. Pediatrics , 8, (January, 1988), pp. 85-92

Chernausek SD, Backeljauw PF, Frank GR. (2007). Long-term treatment with recombinant insulin-like growth factor (IGF)-I in children with severe IGF-I deficiency due to growth hormone insensitivity. J Clin Endocrinol Metab, 92, 5, (May, 2007), pp. 902-910

Collett-Solberg PF, Misra M. (2008). The role of recombinant human insulin-like growth factor-I in treating children with short stature. J Clin Endocrinol Metab, 93, 1 (January, 2008), pp. 10-18

Dattani MT, Robinson IC. (2000). The molecular basis for developmental disorders of the pituitary gland in man. Clin Genet, 57, 5, (May, 2000), pp. 337-46

Dattani MT, Martinez-Barbera JP, Thomas PQ et al. (1999). HESX1: a novel gene implicated in a familial form of septo-optic dysplasia. Acta Paediatr, 88(Suppl), 433 (May, 1999), pp. $49-54$ 
Deladoëy J, Flück C, Büyükgebiz A et al. (1999). Hot spot" in the PROP1 gene responsible for combined pituitary hormone deficiency. J Clin Endocrinol Metab, 84, 5 (May, 1999), pp. $1645-50$

Frindik JP. (2001). Pituitary morphologic anomalies and magnetic resonance imaging in pediatric growth hormone deficiency. The Endocrinologist , 11, 4 (July/August, 2004 pp. 289-295

Frohnert B. Miller BS. (2009). Developmental Disorders of the Anterior Pituitary, Pediatric Endocrinology and Inborn Errors of Metabolism, K. Sarafoglou, GF Hoffman, KS Roth, pp. 487-494, McGraw Hill Medical, 978-0-07-143915-2, New York

Binder G, Weidenkeller M, Blumenstock G et al. (2010). Rational approach to the diagnosis of severe growth hormone deficiency in the newborn. J Clin Endocrinol Metab , 95, 5, (May, 2010), pp. 2219-26

Guevara-Aguirre J, Vasconez O, Martinez V et al. (1995). A randomized double-blind, placebo controlled trial on safety and efficacy of recombinant human insulin-like growth factor-I in children with growth hormone receptor deficiency. J Clin Endocrinol Metab, 80, 4, (April, 1995), pp. 1393-1398

Hendriks-Stegeman, B I, Augustijn KD, Bakker B et al. (2001). Combined pituitary hormone deficiency caused by compound heterozygosity for two novel mutations in the POU domain of the Pit1/POU1F1 gene. J Clin Endocrinol Metab, 86, 4, (April, 2001), pp. $1545-50$

Hintz RL. (1995). The prismatic case of Creutzfeldt-Jacob disease associated with pituitary growth hormone treatment. J Clin Endocrinol Metab, 80, 8, (August, 1995), pp. 22982301

Jorgensen JOL, Blum WF, Moller N et al. (1991). Short-term changes in insulin-like growth factors (IGF's) and IGF-binding protein-3 after different modes of intravenous growth hormoen $(\mathrm{GH})$ exposure to $\mathrm{GH}$-deficient patients. J Clinical Endocrinol Metab, 72, 3, (March, 1991), pp. 582-587

Kofoed EM, Hwa V, Little B et al. (2003). Growth hormone insensitivity associated with a STAT5b mutation. New England Journal of Medicine, 349, 12, (September, 2003), pp. 1110-1112

Laron Z, Lillos P, Klinger B (1993). Growth curves for Laron syndrome. Arch Dis Child, 68, 6, (June, 1993), pp. 768-770

Laron Z, Pertzelan A, Mannheimer S. (1966). Genetic pituitary dwarfism with high serum concentrations of growth hormone--a new inborn error of metabolism? Israel Journal of Medical Science, 2, 2, (March/ April, 1966), pp. 152-155

Machinis, K., J. Pantel, Netchine I et al. (2001). Syndromic short stature in patients with a germline mutation in the LIM homeobox LHX4. Am J Hum Genet, 69, 5, November, 2001), pp. 961-8

Malvagia S, Poggi GM, Pasquini E et al. (2003). The de novo Q167K mutation in the POU1F1 gene leads to combined pituitary hormone deficiency in an Italian patient. Pediatr Res, 54, 5, (November, 2003), pp. 635-40

Netchine I, Sobrier ML, Krude H et al. (2000). Mutations in LHX3 result in a new syndrome revealed by combined pituitary hormone deficiency. Nat. Genet. 25, 2, (June, 2000), pp. 182-6

Nilsson O, Marino R, De Luca F et al. (2005). Endocrine regulation of the growth plate. Hormone Research, 64, 4, (April, 2005), pp. 157-165 
Ooi GT, Cohen FJ, Tseng LY et al. (1997). Growth hormone stimulates transcription of the gene encoding the acid-labile subunit (ALS) of the circulating insulin-like growth factor-binding protein complex and ALS promoter activity in rat liver. Mol Endocrinol 11, 7. (June, 1997), pp. 997-1007

Parks JS, Nielson PV, Sexton LA et al. (1985). An effect of gene dosage on production of human chorionic somatomammotropin. J Clin Endocrinol Metab 50, 5, (May, 1985), pp. 994-997

Raben MS. (1958). Treatment of a pituitary dwarf with human growth hormone. J Clin Endocrinol Metab, 18, 8, (August, 1958), pp. 901-903

Rinderknecht E, Humbel RE. (1978). The amino acid sequence of human insulin-like growth factor I and its strucutral homology with proinsulin. J. Biol. Chem, 253, 8, (April, 1978), pp. 2769-2776

Rinderknecht E, Humbel RE. (1978). Primary structure of human insulin-like growth factor II. FEBS Lett, 89, 2, (May, 1978), pp. 283-286

Root AW, Kemp SF, Rundle AC et al. (1998). Effect of long-term recombinant growth hormone therapy in children National Cooperative Growth Study, USA, 1985-1994. J Pediatr Endocrinol Metab, 11, 3, (March, 1998), pp. 403-412

Rosenbloom AL. (2000). IGF-I treatment of growth hormone insensitivity. In: IGF in Health and Disease, R. G. Rosenfeld and C. T. Roberts. pp. 739-770, Humana Press, Inc., Totowa, NJ

Rosenfeld RG (2005). The IGF system: new developments relevant to pediatric practice. Endocr Dev, 9,1, (January, 2005), pp. 1-10

Rosenfeld RG, Rosenbloom RL, Guevara-Aguirre J. (1994). Growth hormone (GH) insensitivity due to pituitary GH receptor deficiency. Endocr Rev, 15, 3, (June, 1994), pp. 369-390

Salemi S, Besson A, Eblé A et al. (2003). New N-terminal located mutation (Q4ter) within the POU1F1-gene (PIT-1) causes recessive combined pituitary hormone deficiency and variable phenotype. Growth Horm IGF Res, 13, 5, (October, 2003), pp. 264-8

Salmon WD, Daughaday WH. (1957). A hormonally controlled serum factor which stimulates sulfate incorporation by cartilage in vitro. J. Lab. Clin. Med, 49, 6, (June, 1957), pp. 825-836

Savage MO, Burren CP, Blair JC et al. (2001). Growth hormone insensitivity: Pathophysiology, diagnosis, clincal variation and future perspective. Hormone Research , 55, Suppl 2, pp. 32-5

Sjogren K, Liu JL, Blad K et al. (1999). Liver-derived insulin-like growth factor-I (IGF-I) is the principle source of IGF-I in blood but is not required for postnatal growth in mice. Proc Natl Acad Sci, USA, 96, 12, (June, 1999), pp. 7088-7092

Woods KA, Camacho-Hübner C, Bergman RN et al. (2000). Effects of insulin-like growth factor I (IGF-I) therapy on body composition and insulin resistance in IGF-I gene deletion, J Clin Endocrinol Metab, 85, 4. (April, 2000), pp. 1407-11

Woods KA, Camacho-Hubner C, Savage MO et al. (1996). Intrauterine growth retardation and postnatal growth failure associated with deletion of the insulin-like growth factor I gene. N. Engl. J. Med., 335, 18 (October, 1996), pp. 1363-1367

Yakar S, Rosen CJ, Beamer WG et al. (2002). Circulating levels of IGF-I directly regulate bone growth and density. J Clin Invest, 110, 6, (September, 2002), pp. 771-781 


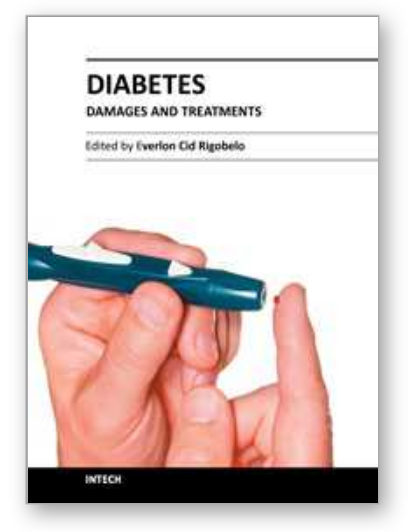

\author{
Diabetes - Damages and Treatments \\ Edited by Prof. Everlon Rigobelo
}

ISBN 978-953-307-652-2

Hard cover, 348 pages

Publisher InTech

Published online 09, November, 2011

Published in print edition November, 2011

Over the last few decades the prevalence of diabetes has dramatically grown in most regions of the world. In 2010, 285 million people were diagnosed with diabetes and it is estimated that the number will increase to 438 million in 2030. Hypoglycemia is a disorder where the glucose serum concentration is usually low. The organism usually keeps the serum glucose concentration in a range of 70 to $110 \mathrm{~mL} / \mathrm{dL}$ of blood. In hypoglycemia the glucose concentration normally remains lower than $50 \mathrm{~mL} / \mathrm{dL}$ of blood. Hopefully, this book will be of help to many scientists, doctors, pharmacists, chemicals, and other experts in a variety of disciplines, both academic and industrial. In addition to supporting researcher and development, this book should be suitable for teaching.

\title{
How to reference
}

In order to correctly reference this scholarly work, feel free to copy and paste the following:

Stephen F. Kemp (2011). The Role of the Pituitary-Growth Hormone-IGF Axis in Glucose Homeostasis, Diabetes - Damages and Treatments, Prof. Everlon Rigobelo (Ed.), ISBN: 978-953-307-652-2, InTech, Available from: http://www.intechopen.com/books/diabetes-damages-and-treatments/the-role-of-the-pituitarygrowth-hormone-igf-axis-in-glucose-homeostasis

\section{INTECH}

open science | open minds

\section{InTech Europe}

University Campus STeP Ri

Slavka Krautzeka 83/A

51000 Rijeka, Croatia

Phone: +385 (51) 770447

Fax: +385 (51) 686166

www.intechopen.com

\section{InTech China}

Unit 405, Office Block, Hotel Equatorial Shanghai

No.65, Yan An Road (West), Shanghai, 200040, China 中国上海市延安西路65号上海国际贵都大饭店办公楼 405 单元

Phone: +86-21-62489820

Fax: $+86-21-62489821$ 
(C) 2011 The Author(s). Licensee IntechOpen. This is an open access article distributed under the terms of the Creative Commons Attribution 3.0 License, which permits unrestricted use, distribution, and reproduction in any medium, provided the original work is properly cited. 